IRA-International Journal of Education \& Multidisciplinary Studies

ISSN 2455-2526; Vol.04, Issue 02 (2016)

Pg. no. 317-322

Institute of Research Advances

http://research-advances.org/index.php/IJEMS

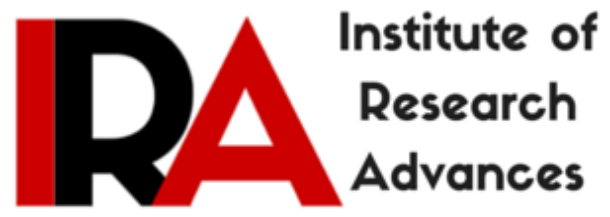

\title{
Productive Oral Feedback - A Successful Tool in English Language Teaching
}

\author{
${ }^{1}$ Dr.Mrumah Al-Enzy \\ Vice Dean, College of Education and Arts \\ Women Division, Northern Border University, ARAR, KSA. \\ ${ }^{2}$ Dr. Roseline Jesudas \\ Dept. of Languages and Translation \\ College of Education and Arts, Women Division \\ Northern Border University, ARAR, KSA.
}

Type of Review: Peer Reviewed

DOI: http://dx.doi.org/10.21013/jems.v4.n2.p10

\section{How to cite this paper:}

Al-Enzy, M., \& Jesudas, R. (2016). Productive Oral Feedback - A Successful Tool in English Language Teaching. IRA International Journal of Education and Multidisciplinary Studies (ISSN 2455-2526), 4(2), 317-322.

doi:http://dx.doi.org/10.21013/jems.v4.n2.p10

(C) Institute of Research Advances

\section{(cc) EY-No}

This work is licensed under a Creative Commons Attribution-Non Commercial 4.0 International License subject to proper citation to the publication source of the work.

Disclaimer: The scholarly papers as reviewed and published by the Institute of Research Advances (IRA) are the views and opinions of their respective authors and are not the views or opinions of the IRA. The IRA disclaims of any harm or loss caused due to the published content to any party. 


\section{ABSTRACT}

This paper discusses about providing a Productive oral feedback on English Language learners' learning process. This study focuses on how the productive oral feedback is an effective tool also, looks at an effective ways of providing oral feedback.

Key Words : Productive oral feedback, performance, errors, mistakes

\section{Introduction}

An oral feedback is very important in English Language Learning. The important aim of providing feedback is to motivate the students to improve their learning process. Always the teachers do the correction in the paper and highlight the surface level errors by underlining, circling wrong spelling/words and few grammatical errors.

Here, the important question is whether the students are considering or valuing these comments or not? Definitely the answer is "no", they do not value the written feedback. We, the teachers realized this fact but automatically we will write the suggestions for the further improvement. Many students do not realize why the comments were written in their paper. Majority of the students are very much focused on their mark.

Learners of English Language have different mindset in their education. Each student adapts their own methods to attain their goal. Always the role of the teacher is very important to direct the students in their language learning process.

\section{Feedback}

The feedback which is given by the teacher must enhance the performance of the students.

The feedback is the message given back to the language learners after their class or an examination. It shows the teacher attitude towards the students and influences their attitude towards us.

We have different ways of providing classroom feedback. We can provide the feedback by oral and in written. Verbal feedback can be expressed by positive or negative notes and corrections. Productive oral feedback motivates the learners to learn language with the positive attitude. Normally students perceive the positive note and react on it.

Penny Ur (1996: 242) mentioned "in the context of teaching in general, feedback is information that is given to the learner about his or her performance of a learning task, usually with the objective of improving this performance."

Littlewood (1981) and Lewis (2002) also point out; feedback means saying learners about their progress and showing them their errors in order to enhance their language learning process.

Productive oral feedback in English Language is not only correcting errors also it needs praising. Waring $\&$ Wong (2009) pointed out that positive feedback is rare to find.

Mc.Namara (1999) and Anyon (2001) quoted as positive feedback shows students that teachers are interested in what they say and at the same time encourage them. 
There are many research studies have focused on oral feedback as an added specific component in the English Language classroom teaching. So, less focus has been identified in the oral feedback because of cross cultural problems.

As a teacher, I am not convinced the way of giving feedback; if we are able to provide a positive feedback which will change the attitude of the language learners also enhance their language learning process. After observing 3 consecutive semesters by providing positive oral feedback we consider that positive oral feedback enhances the language learning process, students are relatively motivated also makes them to feel comfortable and confident.

\section{Focus of the Study}

The main aim of this study is to find out how the productive oral feedback approach is the most useful and successful tool in the undergraduate language teaching classrooms in Saudi Arabia.

Usually feedback point out only the errors and the mistakes, on the whole if we notice the feedback must be negative. These negative feedbacks are ineffective also, not considered by the students. In real, there are many students dropped the course because of an ineffective negative written feedback. This situation forced to find out an effective method of giving feedback to motivate the students to continue the course.

Oral Productive feedback is more useful than written feedback. When we are giving oral productive feedback, both the student and the teacher have the chance to identify the problems and the causes of it. This understanding helps the teacher to give the suitable effective feedback as well provide materials and adapt suitable teaching strategy for the improvement. During this kind of direct interaction, the teacher can ask questions to students to get the clear idea about the student. Also, this strategy enables the student to express their view more clearly, which will help the teacher to understand the real difficulty and offer the required input.

When do the students need the feedback? As a teacher, we should understand the importance of timing to offer the positive oral feedback to enhance students' performance.

\section{Over All Problem}

The overall problem is not offering feedback particularly productive oral feedback by the teachers that the students expect from the teachers, which affects the students' language learning process.

\section{Methodology}

To get the general idea of the productive oral feedback, the research has been conducted for three consecutive semesters during the first quiz, second quiz and midterm. This survey conducted among 3 different groups, students from same level and the groups taught by the same teacher.

\section{Participants}

The students those who are scored average and below average are the target participants of this study. Normally students' do not like to discuss about their performance in front of other students so, considering them and met them individually. 


\section{Observation and Analysis}

Table-1- Performance in Quiz-1

\begin{tabular}{|l|l|}
\hline Total No. of Students & 46 \\
\hline Total No. of Students Passed & 31 \\
\hline Total. No. of Students Failed & 15 \\
\hline Pass \% & 67.4 \\
\hline CLASS AVERAGE & $3.32 / 5$ \\
\hline GRADE & D+ \\
\hline
\end{tabular}

Table-2- After giving productive oral feedback - performance in Quiz-2

\begin{tabular}{|l|l|}
\hline Total No. of Students & 46 \\
\hline Total No. of Students Passed & 38 \\
\hline Total. No. of Students Failed & 18 \\
\hline Pass \% & 82.60 \\
\hline CLASS AVERAGE & $4 / 5$ \\
\hline GRADE & B \\
\hline
\end{tabular}

Table-3- Performance

in Midterm

\begin{tabular}{|l|l|}
\hline Total No. of Students & 46 \\
\hline Total No. of Students Passed & 42 \\
\hline Total. No. of Students Failed & 4 \\
\hline Pass \% & 91.30 \\
\hline CLASS AVERAGE & $16 / 20$ \\
\hline GRADE & B \\
\hline
\end{tabular}

Table-4-Performance in Final Examination

\begin{tabular}{|l|l|}
\hline Total No. of Students & 46 \\
\hline Total No. of Students Passed & 44 \\
\hline Total. No. of Students Failed & 2 \\
\hline Pass \% & 95.65 \\
\hline CLASS AVERAGE & $42 / 60$ \\
\hline GRADE & D \\
\hline
\end{tabular}


Graph-1- performance Analysis

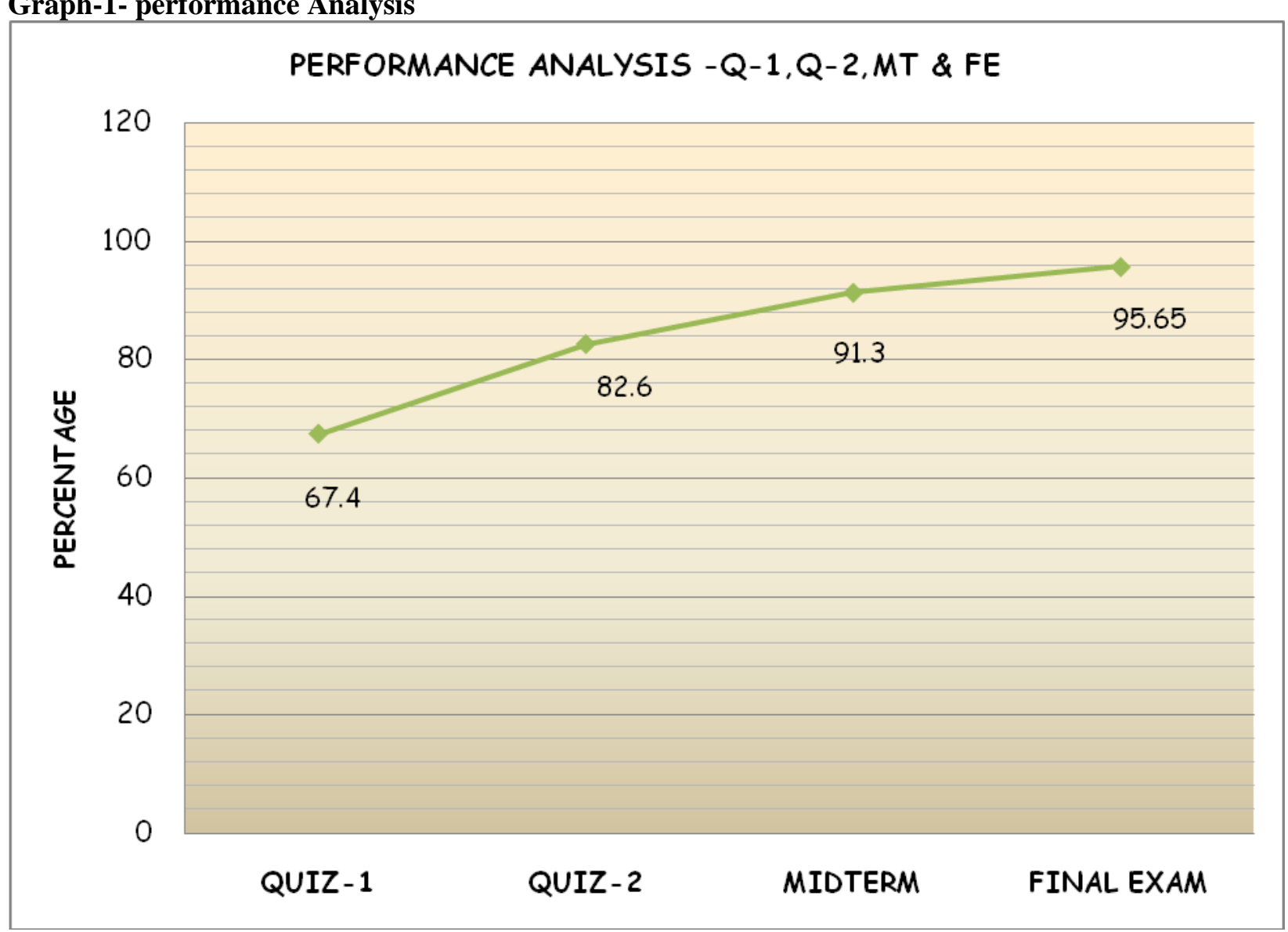

\section{Implications from the Analysis}

The analysis of the average and below average student's performance was observed after each quiz, midterm and final examination. Found the difference in the performance of the students, the students those who were secure less than 2.5 out of 5 got 4.5 and 5 marks, the same way midterm marks were also considered, the final exam performance was observed and found great difference in the performance of the students. These observations revealed an effective impact on the performance of students by providing productive oral feedback.

Giving productive oral feedback to learners is likely to encourage them to learn English language.

\section{Productive oral feedback: A Sample Overview}

Learners need to feel that they are going to make a progress by taking this productive oral feedback. The teachers are responsible for creating a comfortable and conducive atmosphere for the students to approach us. The important aspects for oral productive feedback are our body language and communicative style.

$>$ Not creating embarrassing situation

$>$ Try to make (our) body language clear, and meaningful

$>$ Be specific, natural and explain the student precisely what you like about their performance and why it is good

$>$ Give open comment and praise about their progress

$>$ Provide a chance to the students to meet us whenever they need

$>$ Offer feedback using simple language

$>$ Reassure the quality and encourage the students 
Convey our expectation from the individual

$>$ Create awareness about the time and the importance of time

$>$ Discuss how to utilize and manage the time

$>$ Convince the students to know the benefits of good study habits

$>$ Provide the valuable information sources

$>$ Understand the pinpoint source of confusion

\section{Conclusion}

To conclude, the normally used and relied on methods of teachers' written feedback on exam performance are not effective. If we really need to develop and promote students' language learning process, implementing new feedback strategy is very important. The routine method of correcting surface level errors and habitual feeds backs are not the useful way to promote the language learners. Sometimes, this kind of usual feedback can lead to feelings of confusion and frustration as well as passive action and indifference in the students' attitude.

Thus, we the teachers are responsible to develop organized forms of feedback to help the students' language learning process. Moreover, teachers need to concentrate and make the students to understand the importance of feedback.

\section{References}

1. Ancker, W. (2000). Errors and Corrective Feedback: Updated Theory and Classroom Practice. English Teaching Forum, 38 (4), 20-25.

2. Anyon, D. (2001). The role of negative and positive feedback in the second language acquisition of the passe compose and impartfait.The Modern Language Journal,85 226-238

3. Giving Student Feedback: 20 Tips to Do It Right by Laura Reynolds, June $11^{\text {th }}, 2013$.

4. Littlewood, W. (1981) Communicative language teaching. Cambridge:Cambrige University Press

5. Mc.Namara, E. (1999), Positive Pupil Management and Motivation: Asecondary Teachers' Guide . London: David Fulton Publishers.

6. Ur. P. (1996) A Course in Language Teaching. Cambridge: Cambridge University Press. 